\title{
Glacier fluctuation in northern and High Asia: historical and methods perspective
}

\author{
A. P. Fedotov ${ }^{1} \cdot$ M. Margold ${ }^{2}$
}

Received: 4 June 2015/Accepted: 12 June 2015/Published online: 30 June 2015

(C) Springer-Verlag Berlin Heidelberg 2015

Glaciers in Asia occupy nowadays much smaller extents than those of the Pleistocene but they still play an important role in alpine ecosystems (e.g., Shahgedanova 2002). Glaciers also pose hazards to society and infrastructure, with avalanches and glacial lake outburst floods being the most destructive of glacier-related natural events (Richardson and Reynolds 2000; Janský et al. 2010; Nie et al. 2013; Wang and Zhang 2014).

Since the end of the Little Ice Age (LIA), glaciers have been retreating almost everywhere around the world, and this process has dramatically accelerated during the recent decades (Fig. 1; WGMS 2013). However, individual glaciers are behaving differently and some have advanced while most have been in retreat (IPCC 2013; Yao et al. 2012). Mountain glaciers are sensitive indicators of climate change (e.g., Dyurgerov and Meier 2000; Haeberli et al. 2004) and to fully understand the connection between changing climate and glacier fluctuations, all the variables of the glacier mass balance need to be assessed at the local and regional scale (Dowdeswell et al. 1997; Oerlemans 2005).

One of the regions where information about glacier changes is still scarce is northern and High Asia (Fig. 1), largely because glaciers of the region are located relatively far from human settlements and some have only been found after the 1940s. For example, Ivanov et al. (2015) have provided the first inventory of glaciers in the

A. P. Fedotov

mix@lin.irk.ru

1 Limnological Institute of the Siberian Branch of RAS, Ulan-Batorskaya St., 3, Irkutsk, Russia

2 Department of Physical Geography, Stockholm University, 10691 Stockholm, Sweden
Barguzinsky Ridge east of Lake Baikal, Russia, in this issue. At the same time, continental glaciers of northern and High Asia are located far from the main sources of moisture and are thus sensitive to climate change (Fujita 2008; Kaser et al. 2010). In this issue, we have collected information about glaciers situated along a southwestnortheast transect from $77^{\circ} \mathrm{E}, 32^{\circ} \mathrm{N}$ (the Western Himalaya, India) to $128^{\circ} \mathrm{E} 65^{\circ} \mathrm{N}$ (the Orulgan Range, Russia; Fig. 2) and fed from different sources of moisture (the North Atlantic, the Arctic and the Indo-Pacific air masses). Because glaciers in our focus area belong to different climate systems, their systematic study across the whole region has the potential not only to assess the climate change at local and regional scales but also to reveal climate change patterns at a larger, continental scale. The papers of this issue cover a variety of glacier-related topics (methods studies, glacier inventories, current glacier dynamics, and paleo-reconstructions), and are based on a range of data, such as satellite imagery, synoptic maps, biogeochemical proxies from proglacial lake bottom sediments and meltwater streams, pollen and oxygen isotope records from snow-ice cores, and high-resolution seismic reflection data.

\section{Methods studies}

Snow-ice sections and cores can be accurately dated by annual layer counting for a depth-age (e.g., Oeschger et al. 1978; Anklin et al. 1998). Nakazawa et al. (2015) show that pollen analysis is a powerful method for distinguishing annual layers in snow pits and ice cores from mountain glaciers where other conventional methods of annual layer identification are unreliable due to significant melting. To prove this, the study, conducted on the Potanin Glacier in 

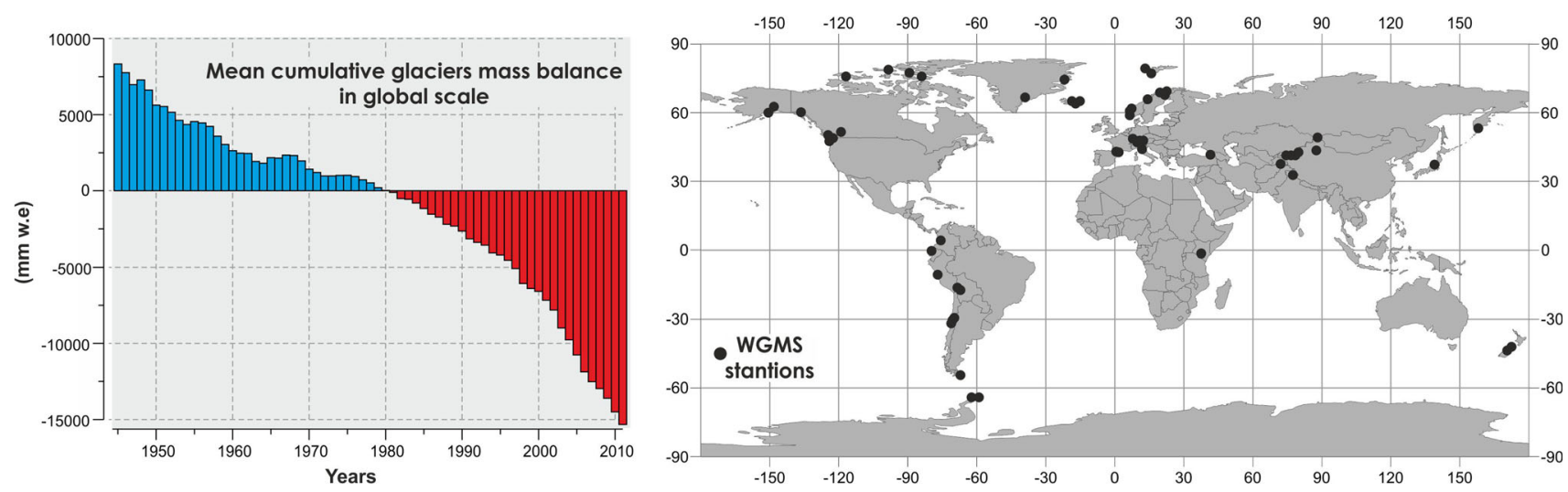

Fig. 1 Changes in mean cumulative specific mass balance of glaciers (left panel) since 1945/46, according to the dataset from the World Glacier Monitoring Service (right panel), adapted from WGMS (2013)

Fig. 2 Location of the papers in this thematic issue. Methods studies are marked in blue, glacier inventories and studies on current glacier dynamics are in red, and paleo-reconstruction and proxy record studies are marked in green

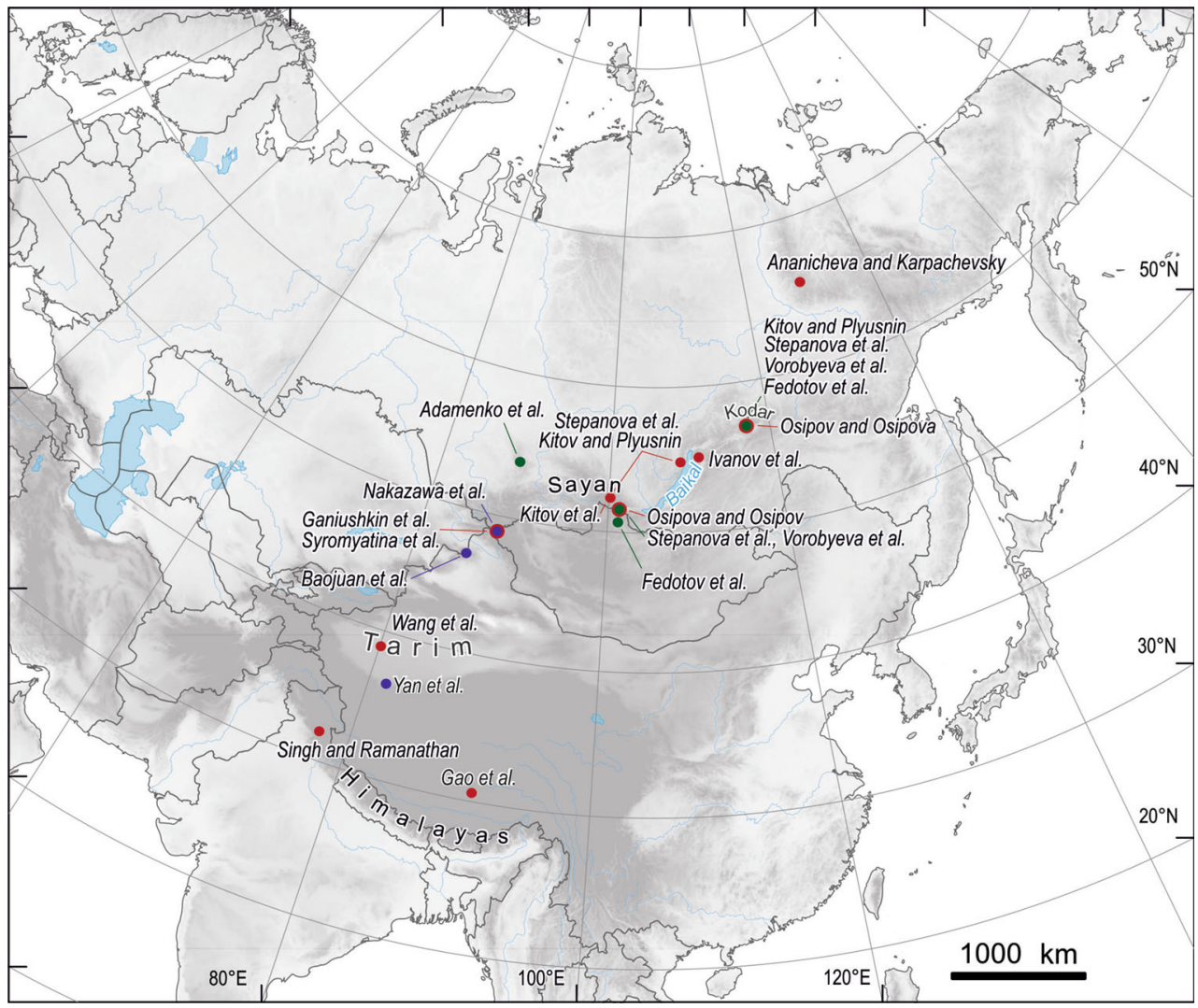

the Mongolian Altai (Fig. 2), compares seasonal layer identification using three pollen taxa against the analysis of $\delta^{18} \mathrm{O}$ record.

Geophysical investigations can be a useful tool for mapping the thickness, morphology, and structure of alpine glaciers (Wu et al. 2013). Three-dimensional geometrical parameters of the Muz Taw glacier (the Sawir Mountains, China; Fig. 2) were studied by Baojuan et al. (2015) using ground penetrating radar data, Landsat imagery, and a digital elevation model. Yan et al. (2015) used pixel-tracking method applied to phased array synthetic aperture radar imagery to study the ice motion of mountain glaciers in the eastern part of the West Kunlun Shan (Tibetan Plateau, China; Fig. 2). The authors found that valley glaciers were flowing actively and exhibited a variety of spatial changes, while ice caps maintained a more stable state without apparent motion in most parts of their surface. 


\section{Glacier inventories and current dynamics of glaciers}

Glacier inventories and studies of current glacier dynamics presented in this issue mostly cover the mountains of Siberia and, in addition, two studies come from the ranges of High Asia. The highest range in Siberia, the Altai (Fig. 2), is described in two papers: Ganiushkin et al. (2015) studied the present state of glaciers in the southeastern Russian and northern Mongolian Altai and their dynamics since the LIA maximum. Their research is based on multiyear in situ observations and an analysis of aerial photos from mid-1960s compared against modern highresolution satellite imagery. 553 glaciers with a total area of $313.4 \mathrm{~km}^{2}$ have been mapped and catalogued, including glaciers that had not been studied before. Syromyatina et al. (2015) focus on a part of the Mongolian Altai, the Tavan Bogd Mountains. They report on the mass balance and dynamics of 63 glaciers in the area, after updating the glacier and rock-glacier inventory for the mountain range.

A number of studies cover the mountain ranges in the broader vicinity of Lake Baikal (Fig. 2). Kitov and Plyusnin (2015) describe the dynamics of small glaciers along a transect from the Eastern Sayan Mountains in the west to the Kodar Mountains in the east (Fig. 2) for the last 50 years. The Eastern Sayan Mountains are the subject of further studies: Kitov et al. (2015) discuss contemporary snow patches and small glaciers in the range, their recent dynamics, and the associated altitudinal biotic zonation of the Eastern Sayan. Osipova and Osipov (2015) studied the links between the changes in regional patterns of atmospheric circulation and the sum of positive temperatures in the glacial zone of the Munku-Sardyk massif (part of the the Eastern Sayan Mountains) for the summers of 2001-2013. Working from synoptic maps (at the mean sea level and 850, 700, and $500 \mathrm{hPa}$ levels), they find that increased air temperature in the study area correlates with the influence of an anticyclonic pressure field, secondary anticyclones (with cloudless weathers), and low gradient field of low pressure over the study area.

Ivanov et al. (2015) provide the first description and inventory of glaciers, glacierets, and snow patches in the Barguzinskiy Ridge, a mountain range stretching in a meridional direction along the eastern shore of Lake Baikal (Fig. 2). Osipov and Osipova (2015) quantify the areal changes of glaciers and mid-summer snow cover in the Kodar Ridge, the highest range of the mountainous region east of Lake Baikal. Their study spans the period from the end of the LIA to 2013 and is based on topographic maps, high-resolution satellite imagery, digital elevation models, and field survey data. Ananicheva and Karpachevsky (2015) analyse the current state of glaciers in the Orulgan
Range, located near the Arctic Cycle in eastern Siberia (Fig. 2), and presents a climatic scenario for the glacier development to 2040-60. Their data are based on ASTER imagery and on the USSR Glacier inventory (1972).

Wang et al. (2015) discusses the changes in the water levels of lakes in the Tarim Basin (China; Fig. 2) with regard to the changes in glacier mass balance in the surrounding ranges. This is done using the Geoscience Laser Altimeter System and high-resolution satellite imagery. The authors find that over the period of 2003-2009, the glacier mass loss was larger in the east Tienshan and Altun Mountains in contrast to the west Kunlun Mountains. Even small glaciers have effects on the water availability in submountain areas and meltwater discharge is an important factor influencing the water chemistry and the seasonality of river runoff ( $\mathrm{Pu}$ et al. 2013; Singh et al. 2015; Zhang et al. 2015). In this context, Singh and Ramanathan (2015) present data about hydrogeochemistry, partial pressure of carbon dioxide and suspended material of meltwater streams from Bara Shigri Glacier (the Western Himalaya, India; Fig. 2) over 2012-2013. Gao et al. (2015) investigate summer hydrological characteristics in glacier and non-glacier catchments in the Nam Co basin in Southern Tibetan Plateau.

\section{Paleo-reconstruction and proxies of glacial events}

The mountains of south-central Siberia were also the subject of studies reconstructing recent or past glacier dynamics indirectly, from proxy records. Stepanova et al. (2015) studied bottom sediments of proglacial lakes in the East Sayan Mountains, the Baikalsky Mountains, and the Kodar Mountains. Bottom sediments, deposited from the end of the LIA to present, were investigated with seasonal resolution, using X-ray fluorescence with synchrotron radiation, inductively coupled plasma mass spectrometry and ${ }^{210} \mathrm{~Pb}$ and ${ }^{137} \mathrm{Cs}$ chronology. The authors reconstruct locally specific periods of intense glacier melting identified from the clastic material transported by glacier meltwater into the proglacial lakes. Another study based on lake sediments is carried out by Fedotov et al. (2015a) for Lake Khubsugul, Mongolia (Fig. 2). The $\delta^{18} \mathrm{O}$ and $\delta^{13} \mathrm{C}$ isotope compositions of ostracod valves, elemental and grain size records were used to reconstruct deglaciation of Northern Mongolia and climate changes for the last $330 \mathrm{ka}$. The increase in the $\delta^{18} \mathrm{O}$ values, a high content of $\mathrm{Br}$, and a low percentage of clay particles were found to positively correspond with high lake bio-productivity and warm climate conditions. Positive $\delta^{13} \mathrm{C}$ values have been linked with high inflow of dissolved inorganic carbonates, and with forest-steppe vegetation. Sharp depletions in the $\delta^{18} \mathrm{O}$ 
values to $1.5-2.5 \%$ have been inferred to originate from glacier meltwater discharge into Lake Khubsugul. A regional analysis of the effects of the meltwater discharge into proglacial lakes on their diatom diversity, in the context of climate and glacier changes, is presented by Vorobyeva et al. (2015). The authors find that dramatic changes in diatom communities might have been induced by low nutrient concentrations in glacial lakes and high turbidity resulting from rapid melting of glaciers and snow patches.

Late Pleistocene and Holocene glaciations in the Kuznetsky Alatau (southern Siberia, Russia; Fig. 2) are reconstructed in the paper of Adamenko et al. (2015). A larger extent of these currently very small glaciers is documented by photographic records for their post-LIA history and by moraines and sedimentary stratigraphy for their Late Pleistocene existence. Glacial Lake Vitim that existed when glaciers descending from the Kodar Mountains blocked the Vitim River during the glacial periods (Enikeev 2009; Margold and Jansson 2011; Margold et al. 2011) is discussed by Fedotov et al. (2015b) for the area of Lake Oron. The authors use high-resolution seismic data to study the Pleistocene-Holocene sedimentary infill of Lake Oron.

\section{Summary}

The papers of this thematic issue show a distinct trend of glacier retreat across the focus area of northern and High Asia from the end of the LIA to the present. However, glaciers located in different regions of the area covered have exhibited varying rates of melting and accumulation over the last decades. Moreover, even glaciers within one mountain range might vary in their mass balance, as a result of local climatic effects. We hope that articles assembled in this issue will add to the knowledge on the pattern of changes in the mountains of northern and High Asia under global and regional climate change.

Acknowledgments We want to express our gratitude to Barbara Kolditz for her unfaltering support with the thematic issue preparation and we reserve our special thanks to the efforts of the manuscripts' reviewers.

\section{References}

Adamenko MM, Gutaka YaM, Solomina ON (2015) Glacial history of the Kuznetsky Alatau mountains. Environ Earth Sci. doi:10. 1007/s12665-015-4621-2

Ananicheva MD, Karpachevsky AM (2015) Glaciers of the Orulgan Range: assessment of the current state and possible development for the middle of the 21st century. Environ Earth Sci. doi:10. 1007/s12665-015-4605-2
Anklin M, Bales RC, Mosley-Thompson E, Steffen K (1998) Annual accumulation at two sites in northwest Greenland during recent centuries. J Geophys Res 103:28775-28783. doi:10.1029/ 98JD02718

Baojuan H, Zhongqin L, Feiteng W, Wenbin W, Puyu W, Kaiming L (2015) Glacier volume estimation from ice-thickness data, applied to the Muz Taw glacier, Sawir Mountains, China. Environ Earth Sci. doi:10.1007/s12665-015-4435-2

Dowdeswell JA, Hagen JO, Björnsson H, Glazovsky AF, Harrison WD, Holmlund P, Jania J, Koerner RM, Lefauconnier B, Ommanney CSL, Thomas RH (1997) The mass balance of circum-Arctic glaciers and recent climate change. Quatern Res 48:1-14. doi:10.1006/qres.1997.1900

Dyurgerov MB, Meier MF (2000) Twentieth century climate change: evidence from small glaciers. Natl Acad Sci 97:1406-1411

Enikeev FI (2009) Pleistocene glaciations in the East Transbaikalia and the Southeast of Middle Siberia. Geomorfologiya 40:33-49 (In Russian)

Fedotov AP, Ignat'ev AV, Velivetskaya TA (2015a) Reconstruction of deglaciation of Northern Mongolia for the last $330 \mathrm{ka}$ BP, inferred from ostracod stable isotope records from Lake Khubsugul. Environ Earth Sci. doi:10.1007/s12665-015-4283-0

Fedotov AP, Chensky DA, Grigorev KA, Stepanova OG, Chensky AG, Chechetkina LG (2015b) Reconstruction of the Late-glacial and Holocene history of Lake Oron (Eastern Siberia, Russia) based on high-resolution reflection seismic data. Environ Earth Sci. doi:10.1007/s12665-015-4642-x

Fujita K (2008) Effect of precipitation seasonality on climatic sensitivity of glacier mass balance. Earth Planet Sci Lett 276:14-19

Gao et al. (2015) Summer hydrological characteristics in glacier and non-glacier catchments in the Nam Co Basin, southern Tibetan Plateau. Environ Earth Sci. doi:10.1007/s12665-015-4643

Ganiushkin D, Chistyakov K, Kunaeva E (2015) Fluctuation of glaciers in the southeast Russian Altai and northwest Mongolia Mountains since the Little Ice Age maximum. Environ Earth Sci. doi:10.1007/s12665-015-4301-2

Haeberli W, Frauenfelder R, Kääb A, Wagner S (2004) Characteristics and potential climatic significance of "miniature ice caps" (crestand cornice-type low-altitude ice archives). J Glaciol 50:129-136

IPCC (2013) The physical science basis. Working group I contribution to the fifth assessment report of the intergovernmental panel on climate change. Cambridge University Press, Cambridge

Ivanov EN, Plyusnin VM, Kitov AD, Kovalenko SN, Balyazin IV, Sofronov AP (2015) Inventory of nival-glacial geosystems in Lake Baikal area (East Siberia, Russia). Environ Earth Sci. doi:10.1007/s12665-015-4446-Z

Janský B, Šobr M, Engel Z (2010) Outburst flood hazard: case studies from the Tien-Shan Mountains, Kyrgyzstan. Limnol Ecol Manag Inland Waters 40:358-364. doi:10.1016/j.limno.2009.11.013

Kaser G, Großhauser M, Marzeion B (2010) Contribution potential of glaciers to water availability in different climate regimes. Proc Natl Acad Sci 107:20223-20227. doi:10.1073/pnas.1008162107

Kitov AD, Plyusnin VM (2015) Nival-glacial dynamics of geosystems in Eastern Siberia (Russia) for the last 50 years. Environ Earth Sci. doi:10.1007/s12665-015-4585-2

Kitov AD, Kovalenko SN, Plyusnin VM, Suvorov EG (2015) Modern changes of the high-mountain landscapes and glaciation in Southern Siberia (Russia) by the example of the Eastern Sayan mountains. Environ Earth Sci. doi:10.1007/s12665-015-4455-y

Margold M, Jansson K (2011) Glacial geomorphology and glacial lakes of central Transbaikalia, Siberia, Russia. J Maps 7:18-30. doi:10.4113/jom.2011.1132

Margold M, Jansson KN, Stroeven AP, Jansen JD (2011) Glacial Lake Vitim, a $3000-\mathrm{km}^{3}$ outburst flood from Siberia to the Arctic Ocean. Quat Res 76:393-396. doi:10.1016/j.yqres.2011.06.009 
Nakazawa F, Konya K, Kadota T, Ohata T (2015) Depositional and summer snow melting features in 2007-2011 on the upstream side of Potanin Glacier, Mongolian Altai, reconstructed by pollen and oxygen isotope analysis. Environ Earth Sci. doi:10. 1007/s12665-015-4436-1

Nie Y, Zhang YL, Ding MJ, Liu LS, Wang ZF (2013) Lake change and its implication in the vicinity of Mt. Qomolangma (Everest), central high Himalayas, 1970-2009. Environ Earth Sci 68:251-265. doi:10.1007/s12665-012-1736-6

Oerlemans H (2005) Extracting a climate signal from 169 glacier records. Science 308:675-677. doi:10.1126/science.1107046

Oeschger H, Schotterer U, Stauffer B, Haeberli W, Röthlisberger H (1978) First results from alpine core drilling projects. Z Gletscherk Glazialgeol 13:193-208

Osipov EY, Osipova OP (2015) Glaciers of the Levaya Sygykta River watershed, Kodar Ridge, southeastern Siberia, Russia: modern morphology, climate conditions and changes over the past decades. Environ Earth Sci. doi:10.1007/s12665-015-4352-4

Osipova OP, Osipov EY (2015) Relationship between recent climate change, ablation conditions of glaciers of the East Sayan Range, Southeastern Siberia, and atmospheric circulation patterns. Environ Earth Sci. doi:10.1007/s12665-015-4488-2

$\mathrm{Pu}$ T, He YQ, Zhu GF, Xin HJ, Cao WH, Niu HW (2013) Hydrochemical characteristics of typical rivers in a temperate glacier basin, China. Environ Earth Sci 68:615-621. doi:10. 1007/s12665-012-1764-2

Richardson SD, Reynolds JM (2000) An overview of glacial hazards in the Himalayas. Quatern Int 65-66:31-47. doi:10.1016/S10406182(99)00035-X

Shahgedanova M (2002) The physical geography of northern Eurasia. Oxford University Press, Oxford

Singh VB, Ramanathan AL (2015) Assessment of solute acquisition processes and suspended sediment concentration in the meltwater of Bara Shigri glacier, Western Himalaya, India. Environ Earth Sci. doi:10.1007/s12665-015-4584-3

Singh VB, Ramanathan AL, Sharma P (2015) Major ion chemistry and assessment of weathering processes of the Patsio glacier meltwater, Western Himalaya, India. Environ Earth Sci 73:387-397. doi:10.1007/s12665-014-3432-1

Stepanova OG, Trunova VA, Zvereva VV, Melgunov MS, Fedotov AP (2015) Reconstruction of glacier fluctuations in the East Sayan, Baikalsky and Kodar Ridges (East Siberia, Russia) during the last 210 years based on high-resolution geochemical proxies from proglacial lake bottom sediments. Environ Earth Sci. doi:10.1007/s12665-015-4457-9

Syromyatina MV, Kurochkin YN, Chistyakov KV (2015) Current dynamics of glaciers in the Tavan Bogd Mountains (Northwest Mongolia). Environ Earth Sci. doi:10.1007/s12665-015-4606-1

Vorobyeva SS, Trunova VA, Stepanova OG, Zvereva VV, Petrovskii SK, Melgunov MS, Zheleznyakova TO, Chechetkina LG, Fedotov AP (2015) Impact of glacier changes on ecosystem of proglacial lakes in high mountain regions of East Siberia (Russia). Environ Earth Sci. doi:10.1007/s12665-015-4164-6

Wang SJ, Zhang T (2014) Spatial change detection of glacial lakes in the Koshi River Basin, the Central Himalayas. Environ Earth Sci 72:4381-4391. doi:10.1007/s12665-014-3338-y

Wang N, Wu H, Wu Y, Chen A (2015) Variations of the glacier mass balance and lake water storage in the Tarim Basin, northwest China, over the period of 2003-2009 estimated by the ICESatGLAS data. Environ Earth Sci. doi:10.1007/s12665-015-4662-6

WGMS (2013) Glacier Mass Balance Bulletin No. 12 (2010-2011). In: Zemp M, Nussbaumer SU, Naegeli K, Gärtner-Roer I, Paul F, Hoelzle M, Haeberli W (eds) ICSU(WDS)/IUGG(IACS)/UNEP/ UNESCO/WMO, World Glacier Monitoring Service, Zurich, Switzerland, publication based on database version, $\mathrm{p}$ 106. doi 10.5904/wgms-fog-2013-1

Wu Z, Liu SY, Zhang SQ, Xiao HL (2013) Internal structure and trend of glacier change assessed by geophysical investigations. Environ Earth Sci 68:1513-1525. doi:10.1007/s12665-0121845-2

Yan S, Liu G, Wang Y, Ruan Z (2015) Glacier surface motion pattern in the Eastern part of West Kunlun Shan estimation using pixeltracking technique with PALSAR imagery. Environ Earth Sci. doi:10.1007/s12665-015-4645-7

Yao TD, Thompson L, Yang W, Yu WS, Gao Y, Guo XJ, Yang XX, Duan KQ, Zhao HB, Xu BQ, Pu JC, Lu AX, Xiang Y, Kattel DB, Joswiak D (2012) Different glacier status with atmospheric circulations in Tibetan Plateau and surroundings. Nat Clim Chang 2:663-667. doi:10.1038/Nclimate1580

Zhang YL, Sillanpaa M, Li CL, Guo JM, Qu B, Kang SC (2015) River water quality across the Himalayan regions: elemental concentrations in headwaters of Yarlung Tsangbo, Indus and Ganges River. Environ Earth Sci 68:4151-4163. doi:10.1007/ s12665-014-3702-y 